\title{
THE LOESS “CAVE” NEAR THE VILLAGE OF SURDUK - AN UNUSUAL PSEUDOKARST LANDFORM IN THE LOESS OF VOJVODINA, SERBIA
}

\section{PSEVDOKRAŠKE JAME V PUHLICI: PRIMER IZ OKOLICE VASI SURDUK (VOJVODINA, SRBIJA)}

\author{
Tin LUKIĆ $C^{1}$, Slobodan B. MARKOVIĆ ${ }^{1}$, Thomas STEVENS ${ }^{2}$, Djordjije A. VASILJEVIĆ ${ }^{1}$, \\ Björn MACHALETT ${ }^{3}$, Nebojša MILOJKOVIĆ ${ }^{1}$, Biljana BASARIN ${ }^{1} \&$ Igor OBREHT $^{1}$
}

\begin{abstract}
UDC 911.2:551.4(497.113)

Tin Lukić, Slobodan B. Marković, Thomas Stevens, Djordjije A. Vasiljević, Björn Machalett, Nebojša Milojković, Biljana Basarin \& Igor Obreht: The loess "cave" near the village of Surduk - an unusual pseudokarst landform in the loess of Vojvodina, Serbia

Loess "caves" (piping caverns, wells, tunnels) exposed in loess cliffs are rare pseudokarst landforms that can be regarded as morphological equivalents to collapse dolines or sinkholes formed in classical karst terrains. This study presents the results of an investigation into a loess cave exposed in a loess cliff on the right bank of the Danube River near the village of Surduk in the Vojvodina region, Serbia. This study provides a first detailed morphologic description of this young pseudokarstic landform formed by piping erosion, probably partly supported with carbonate dissolution. The loess "cave" has a height of approximately $12 \mathrm{~m}$ and average diameter of around $3.5 \mathrm{~m}$. In the middle of the cave ceiling there is a window. Observations indicate that over the last several years, the morphological characteristics of the landform have been stable. The main aim of this study is to provide a better understanding of the evolution of the piping process in the thick loess-paleosol sequences in the Vojvodina region, northern Serbia. A key role in the genesis of this landform was the short distance between an initial loess doline and a cliff exposing loess sediments, providing the possibility for the lateral removal of loess material. The presence of Robinia pseudoakacia trees around the initial depression modulated the evolution of the doline and provides support for the loess cavern roof. The nature of the dynamic erosional processes on the steep cliffs of the soft loess sediment indicates a very limited lifetime of this pseudokarstic landform.
\end{abstract}

Keywords: loess, pseudokarst landforms, Serbia, Surduk.
Izvleček

UDK 911.2:551.4(497.113)

Tin Lukić, Slobodan B. Marković, Thomas Stevens, Djordjije A. Vasiljević, Björn Machalett, Nebojša Milojković, Biljana Basarin \& Igor Obreht: Psevdokraške jame v puhlici: primer iz okolice vasi Surduk (Vojvodina, Srbija)

Jame v puhličnih klifih so precej redka psevdokraška oblika, ki bi bila lahko morfološki ekvivalent udornicam ali vrtačam na klasičnem krasu. $\mathrm{V}$ članku predstavimo raziskave $\mathrm{v}$ jami, $\mathrm{z}$ vhodom v puhličnem klifu na desnem bregu Donave pri vasi Surduk v Vojvodini. Študija je prvi natančen morfološki opis te mlade psevdokraške oblike, nastale $\mathrm{z}$ cevčenjem (piping erosion) erozijo. Jama je visoka približno $12 \mathrm{~m}$, povprečen premer je približno $3,5 \mathrm{~m}$. V sredini stropa je okno. Opazovanja kažejo, da se oblika jame v zadnjih nekaj letih ni spreminjala. Naš namen je poglobiti razumevanje procesov cevčenja $\mathrm{v}$ debelih puhličnih nanosih Vojvodine. Ključno za genezo jame je bližina med začetno depresijo $\mathrm{v}$ puhlici in puhličnega klifa, ki omogoča lateralno odnašanje prsti. Prisotnost dreves Robinia pseudoakacia $\mathrm{v}$ okolici začetne depresije nudi oporo krušljivemu jamskemu stropu. Zaradi erozijskih procesov na strmih puhličnih klifih je življenska doba psevdokraških pojavov kratka.

Ključne besede: puhlica, psevdokraške oblike, Srbija, Surduk.

${ }^{1}$ Chair of Physical Geography, Department of Geography, Tourism and Hotel Management, Faculty of Sciences, University of Novi Sad, Trg D. Obradovića 3, 21000 Novi Sad, Serbia, e-mail: slobodan.markovic@dgt.uns.ac.rs

${ }^{2}$ Centre for Quaternary Research, Department of Geography, Royal Holloway, University of London, Egham, Surrey, TW20 0EX, UK, e-mail: thomas.stevens@rhul.ac.uk

${ }^{3}$ Humboldt-University of Berlin, Department of Geography, Unter den Linden 6, D-10099 Berlin, Germany,

e-mail: b.machalett@nakula.de

Received/Prejeto: 04.11.2009 


\section{INTRODUCTION}

The term pseudokarst has been used to describe a diversity of landforms evolved in various types of commonly insoluble, as well as chemically soluble rocks, sediments and soils (e.g. Otvos 1976; Self \& Mullan 2005; Wray 1997). According to Halliday (2007) loess deposits fall into the badland and piping pseudokarst type, i.e. the horizontal, graded or vertical grain-by-grain removal of particles by channelized groundwater flow in a granular material and in some poorly soluble rocks. In recent years, extensive piping caves have become recognized as important individual features, with piping first being recognized in loess and loess-like silt in China. However, natural caves are not characteristic of loess topography (Halliday 2007).

characteristics, the morphology of loess-covered areas is partly similar to classic karstic landscapes.

Vojvodina is a region in northern Serbia, located in the south-eastern part of Carpathian (Pannonian) Basin. More than $60 \%$ of this lowland area is covered by loess and loess-like sediments (Fig. 1). Typical loess sediments in the Vojvodina region contain between 10 and 35\% carbonate content (Marković et al. 2004, 2005a, 2006, 2007, 2008; Bokhorst et al. 2009). Because of its sedimentological characteristics, the significant thickness of loess-paleosol sequences, and the generally relatively dry climate in the Vojvodina region, many pseudokarst landforms have been formed and preserved on loess covered terrain. However, and in spite of worldwide distribution

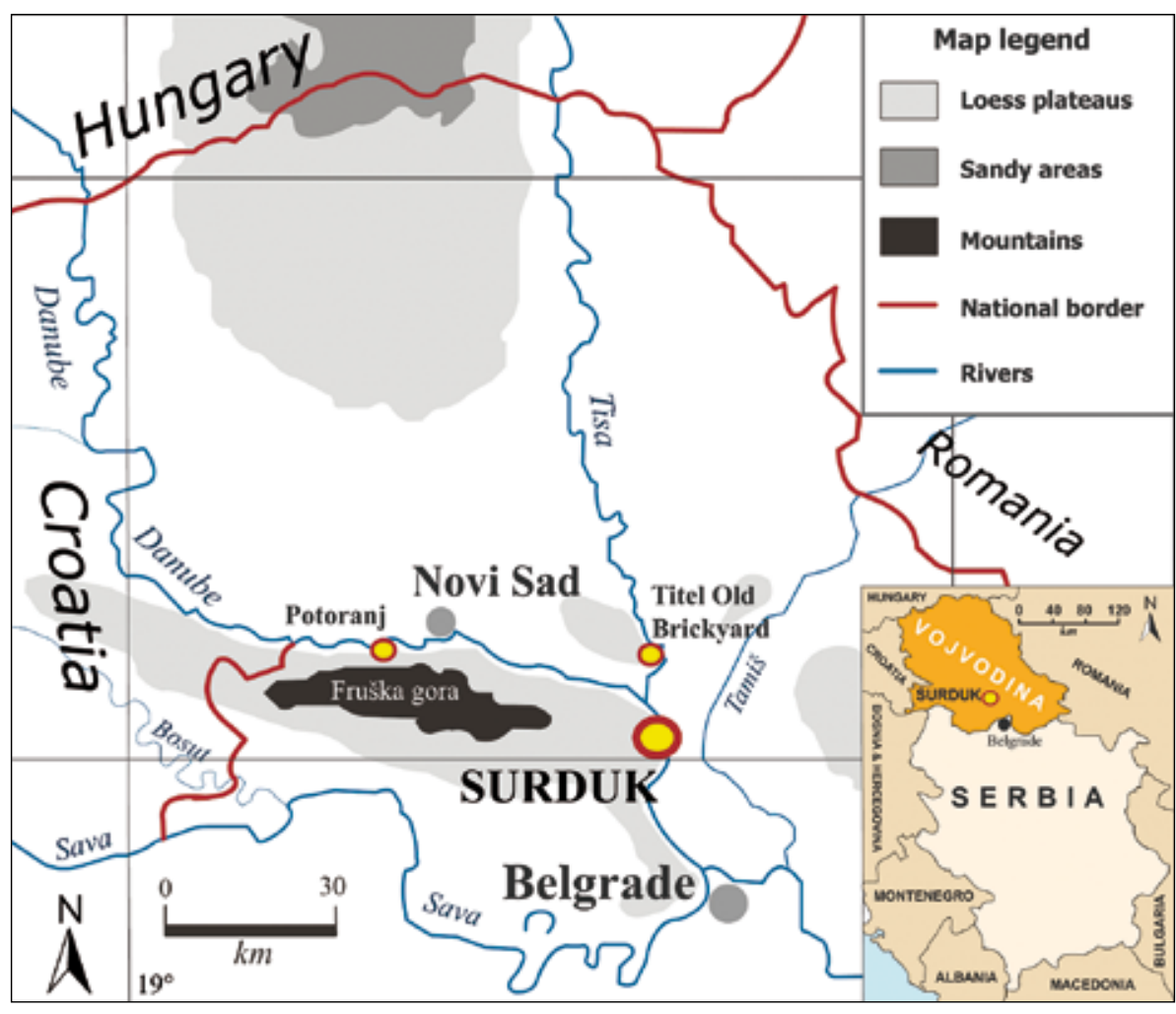

Fig.1: Map of loess distribution in Vojvodina and adjacent regions, showing the geographical position of the investigated section and other main loess sites (modified after Marković et al. 2004).

Loess is a fine-grained, clastic sedimentary rock primary of aeolian origin which covers nearly $10 \%$ of Earth's surface (e.g. Heller \& Evans 1995). There are several typical features of loess that control the ways, in which it is affected by different erosive processes. Its high porosity $(30-50 \%)$ and significant carbonate content explains its great permeability and moisture absorption capacity (e.g. Leger 1990). Due to these of the loess sediments, the international geomorphological literature related to pseudokarst loess landforms is relatively sparse (e.g. Fuller 1922; Leger 1990; Kertesz \& Schweitzer 1991; Rozycki 1991; Rogers et al. 1994; Zhu et al. 2002; Móga \& Németh 2005; Gillijns et al. 2005; Zeeden et al. 2007; Tang et al. 2008).

Due to the prominence of loess cliffs exposing loess and paleosol horizons along the steep-sided right bank of the Danube in Vojvodina (Marković et al. 2009b) it is not surprising that these loess-paleosol exposures along the right bank of the Danube River were, for the first time, described by Count Luigi Ferdinando Marsigli in the first volume of Danubius Pannonico Mysicus (Marsigli 1726). This first scientific description of the European lloess-paleosol sequences recognised many sedimentological characteristics which remain valid to this day (Marković et al. 2004, 2009a). Since then, many, mostly regional, stratigraphic loess investigations have been conducted in this region (e.g. Cholnoky 1910; Bukurov 1953, 1975; Zeremski 1955a, b). However, in spite of this long research tradition, understanding of the geomorphologic characteristics of the loess landforms in the Vojvodina region is still poorly known. 
Piping has been increasingly recognized as significant hill slope geomorphologic and hydrological process in loess regions. Zhu et al. (2002) suggested based on field monitored data that tunnel erosion is a major geomorphologic process in the hilly loess regions in China. However, the pipeflow erosion process in loess sediments is still not fully understood. In spite of the high frequency of loess piping systems (Zhu et al. 2002) these under- ground landforms are directly visible only on the steep loess cliffs. Loess caves could be accepted as landforms similar to collapse dolines or sinkholes (e.g. Šušterič 2000; Šebela \& Čar 2000) in classical karst terrains. Thus, this study will present detailed data and interpretations on the morphology and genesis of the investigated Surduk loess "cave".

\section{SETTING AND METHODS}

The investigated site is located on the right bank of the Danube River ( $\varphi 45^{\circ} 04^{\prime} 49^{\prime \prime} \mathrm{N}$ and $\left.\lambda 20^{\circ} 19^{\prime} 75^{\prime \prime} \mathrm{E}\right)$, about $40 \mathrm{~km}$ northwest of Belgrade, Serbia. The remarkable loess cliffs near Surduk village (Figs. 2 and 3) form the steep-sided right bank of the Danube River, from Vukovar (Croatia) to Belgrade (Serbia). Fig. 2 shows a

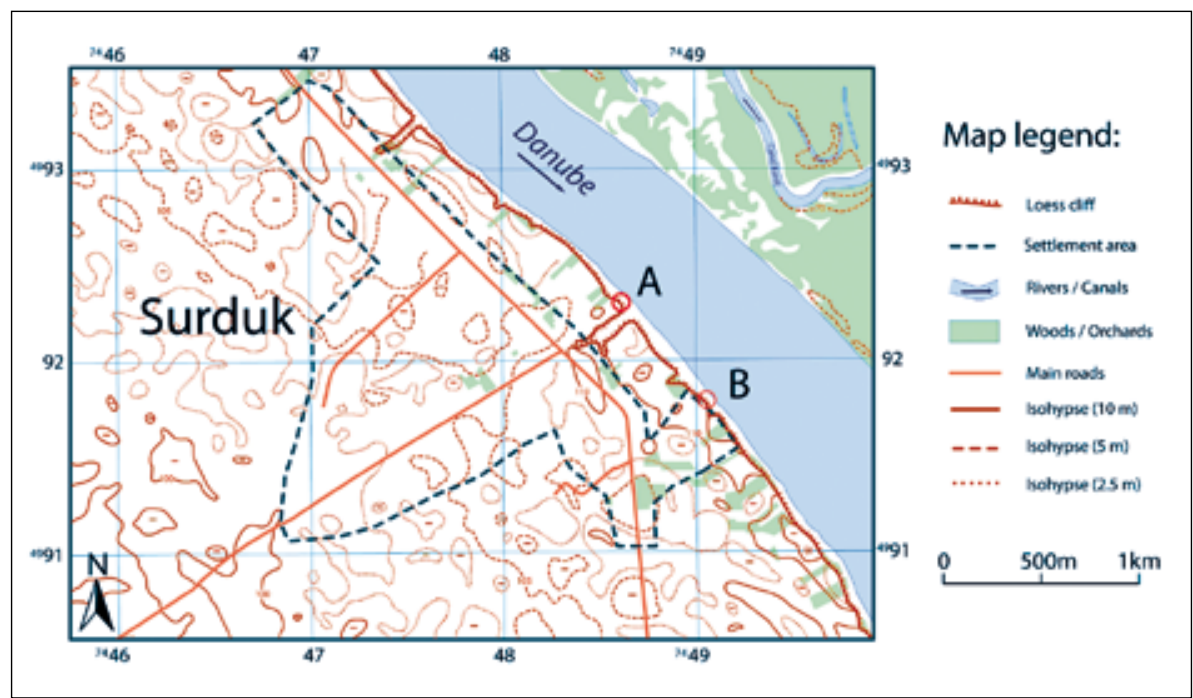

Fig. 2: Topographic map of the study area showing the location of the investigated loess doline (A) and section B referred to by Fuchs et al. (2008) and Antoine et al. (2009) near the village of Surduk.

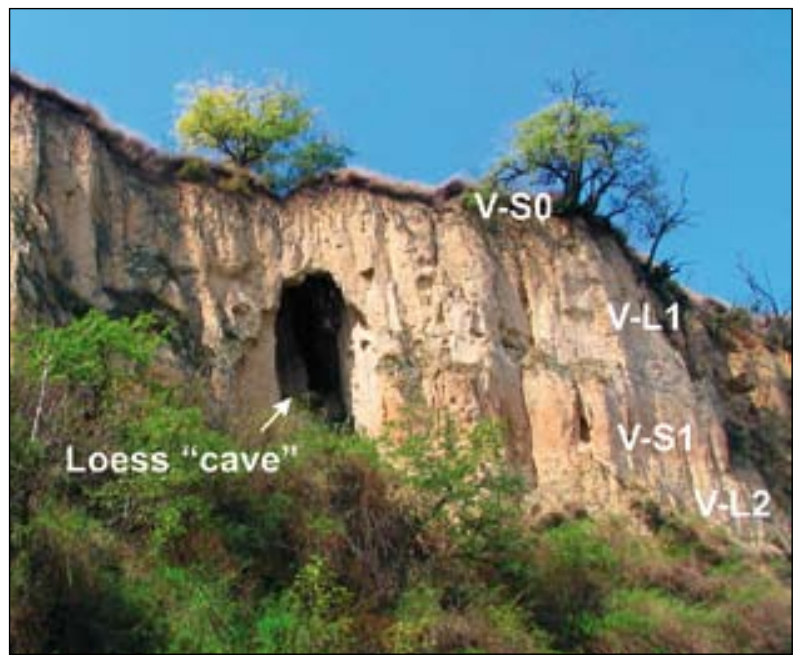

detailed description of the topography surrounding the investigated site. It has been created based upon topographic map sheet Zrenjanin 4-3 (1:25000; Military Geographic Institute of Serbia 1995) and following results of field investigations. Erosive action of fluvial processes of the Danube River forms steep loess cliffs on the right bank. About 40 $m$ thickness of intercalated loess and paleosol sequence is exposed on this bank near Surduk village and consists thick last and penultimate glacial loess layers V-L1 and V-L2 respectively [stratigraphic labels are distinguished according to Marković et al. (2008)] as well as fossil chernozems V-S1 and V-S2, similar to the recent Holocene soil V-S0 at the top of the loess plateau. This sequence covers the last two glacial-interglacial cycles.

Identified variations in grain size distribution (Fig. 5) at the site coincide well with pedostratigraphy (Antoine et al. 2009). Generally, the pedogenetic horizons have higher proportion of clay-sized material than the loess layers. The contact between loess cliffs and the alluvial plain of the Danube River is area of intensive relief dynamics. In the contrast, the plateau surface

Fig. 3: Loess cave near the village of Surduk, Serbia (Photo: T. Lukić). 
provides more low relief morphology with small hypsometric differences. However, the surface of the plateau is entirely covered by a system of depressions morphologically similar to dolines in karst regions. The depressions have different shapes and their length varies between 30 and $240 \mathrm{~m}$. Their width rarely exceeds $200 \mathrm{~m}$. The depth of the depressions within aggrandizements reaches ca. $3 \mathrm{~m}$ (Fig. 2).

The loess "cave" is exposed in the steep loess cliff near the end of a gully connecting the centre of Surduk village and the Danube bank (Figs. 2 and 3). Field investigations started in 2004 and since then general changes in morphometric features of the loess cave have been monitored. Detailed field investigations were carried out in June 2007 and they involved morphometric measuring and mapping of the cave. After field investigations, cave profiles were projected on an idealized plane in SE-NW and NE-SW directions. Recent field investigations were also carried out during 2008 and 2009.

\section{RESULTS AND DISCUSSION}

\section{Lithology, stratigraphy and main sedimentological characteristics}

A description of the loess-paleosol sequence near the investigated loess cavern is presented on Fig. 4. It is very similar to the description of a section situated about $700 \mathrm{~m}$ downstream to the southeast (B in Fig. 2) conducted by Antoine et al. (2009). In spite of different thickness between these sections consistent pedostratigraphy and detailed sedimentologic, geochemic and chronostratigraphic data presented by Fuchs et al. (2008) and Antoine et al. (2009) could therefore be used to aid interpretation of the morphological evolution presented in this study.

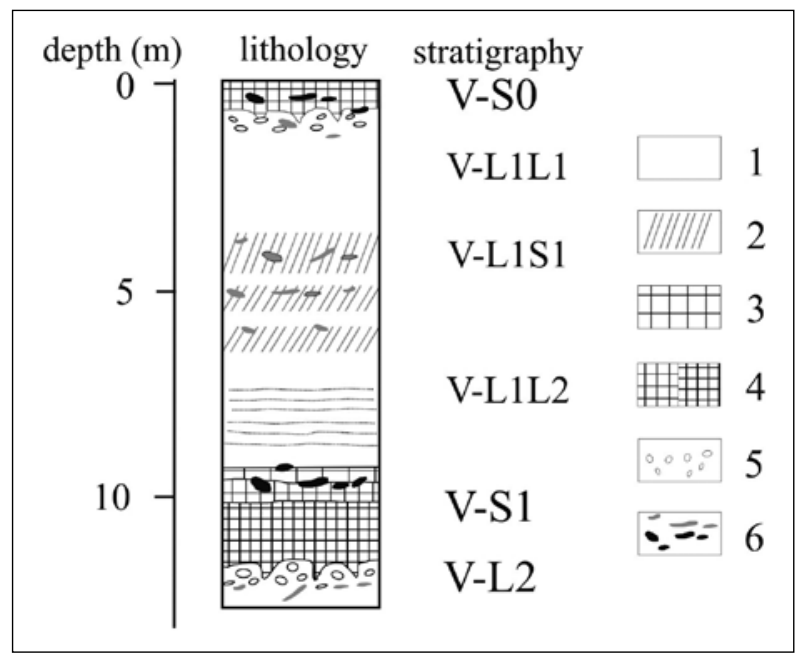

Fig. 4: Description of loess-paleosol sequences near the investigated loess doline.

Legend: 1. Loess; 2. Embryonic pedogenic layer; 3. A horizon; 4. Ah horizons; 5. carbonate concretions; 6. krotovinas.

Fig. 5 presents a comparison between descriptions of the two neighbouring profiles and variations in grain size parameters with depth according to Antoine et al. (2009). Recent soil V-S0 and fossil pedocomplex V-S1 have relative similar grain size distributions, characterized by high clay contents. Generally, loess layers V-L1L1 and V-L1L2 are composed of coarser material than either of the V-S0 or V-S1 soils or the weakly developed middle pleniglacial pedocomplex V-L1S1. In the lower pleniglacial loess unit V-L1L2, sandy layers are exposed.

The distribution of grain size fractions of loess-paleosol sequences appears to have a modifying effect on erosion intensity. Coarser grained porous loess layers characterised by intensive water percolation are less resistant to erosion than clay rich paleosols, as witnessed by the loess cavern having its greatest width in the last glacial loess V-L1 layer. At the contact with paleosol VS1, a small platform has been formed, likely as a consequence of greater resistance to erosion of clay rich material comprising V-S1 (Figs. 6 and 7).

\section{Morphometry}

Tab.1 shows morphometric characteristics of the investigated loess "cave" during field research in June

Tab.1: Morphometric characteristics of the loess cave near Surduk village.

\begin{tabular}{|l|r|}
\hline \multicolumn{2}{|l|}{ Morphometric features } \\
\hline Denivelation & $12.1 \mathrm{~m}$ \\
\hline Height of entrance & $8.15 \mathrm{~m}$ \\
\hline Maximum width of the entrance & $3.1 \mathrm{~m}$ \\
\hline Maximum width of the cave & $3.4 \mathrm{~m}$ \\
\hline Total volume & $51.5 \mathrm{~m}^{3}$ \\
\hline $\begin{array}{l}\text { Height of eroded loess blocks at the base of } \\
\text { the cave }\end{array}$ & $1.53 \mathrm{~m}$ \\
\hline Thickness of uneroded loess roof & $3.95 \mathrm{~m}$ \\
\hline Maximum width of cave window & $4.15 \mathrm{~m}$ \\
\hline
\end{tabular}




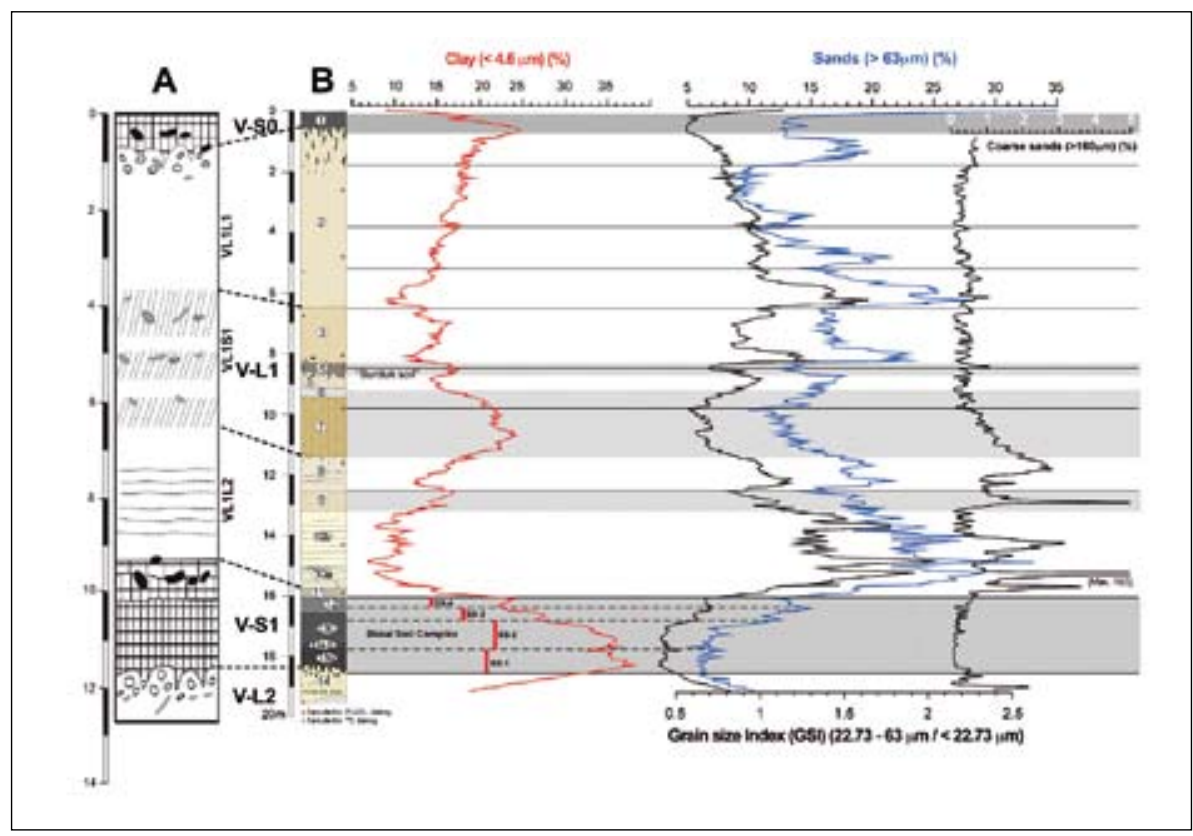

Fig. 5: Comparison between the two neighbouring loess-paleosol profiles and variations in grain size parameters according to Antoine et al. (2009).
2007. Recent field investigations that were also carried out during 2008 and July 2009 reveal no significant morphological changes. Only minor changes beneath the base of the cave floor, in a small canal formed in colluval material at the bottom of the loess cliff were determined, presumably initiated by pluvial erosion processes. The total height of the cave is $12.1 \mathrm{~m}$, and the greatest width is $3.7 \mathrm{~m}$. These dimensions include height from the bottom of the cave entrance on loess cliff to the cavern roof. The height of the entrance on loess cliff is significantly smaller $(8.15 \mathrm{~m})$, and its greatest width is $3.1 \mathrm{~m}$.

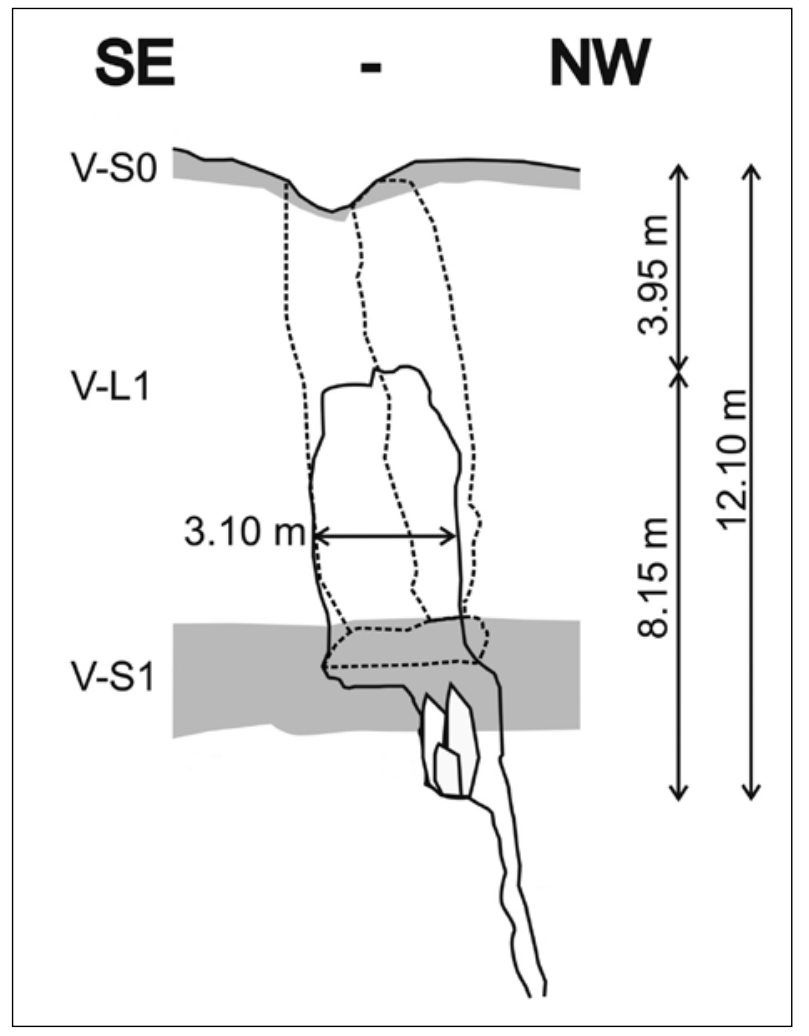

Fig. 6: Loess cave profile projected on the SE-NW plane.

Fig. 7: Loess cave profile projected on a NE-SW plane.

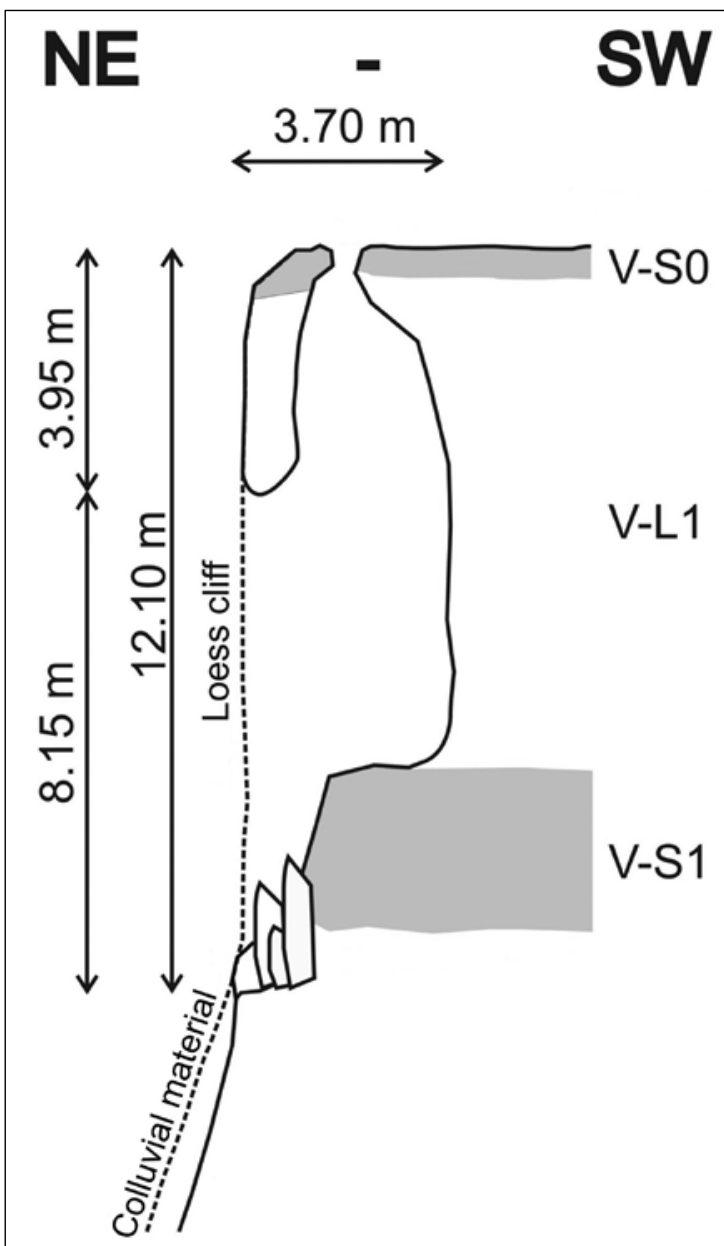

ACTA CARSOLOGICA 38/2-3 - 2009 
The total volume is approximately $51.5 \mathrm{~m}^{3}$. In the centre of the cave roof there is an erosional cave window to the surface, the longest axis of which is $4.15 \mathrm{~m}$ and the narrowest width is $1 \mathrm{~m}$ (Fig. 8).

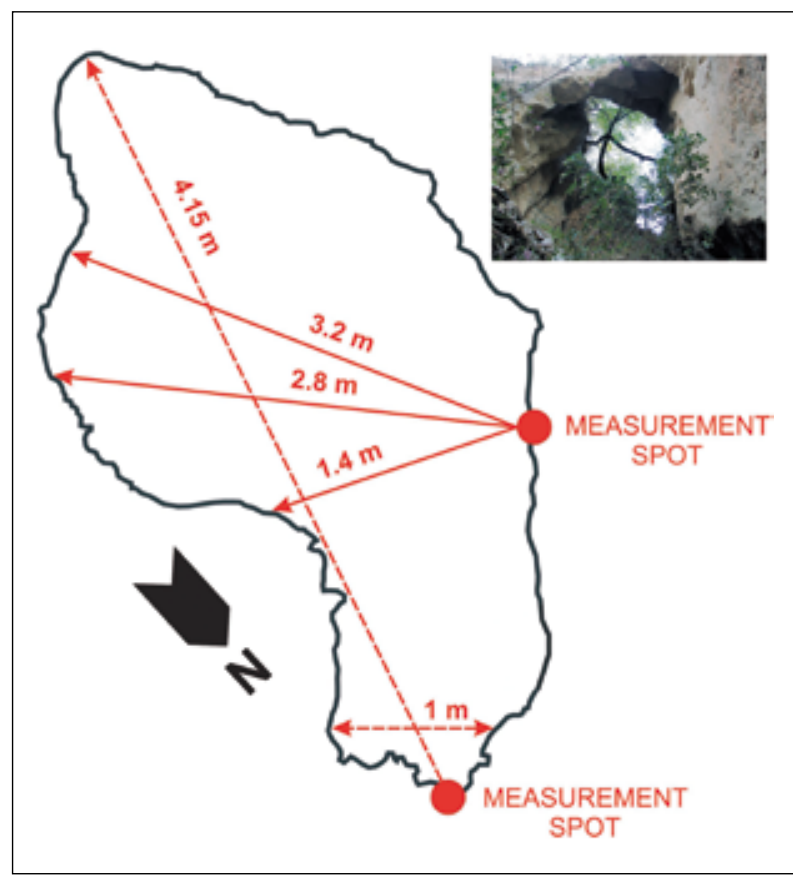

Fig. 8: Morphometric features of the loess "cave" window.

Fig. 6 shows the cave profile projected on a plane in the SE-NW direction, which is parallel to the plane of the loess cliff with the cave entrance. In the loess "cave" base there is an internal canal, which spreads from the cave window to paleosol layer V-S1. Because of the intense erosion, loess material is being deposited on the lower cascade. Fig. 7 shows the cave profile projected on a plane in a NE-SW direction, perpendicular to the plane of the loess cliff with the cave entrance. This profile illustrates paleosol V-S1's influence to the morphology of the cave itself, largely a factor of the greater clay content of the paleosol. The almost vertical internal canal in the cave ends on the contact with paleosol V-S1 and forms a small platform, which gradually descends to the bottom of the cave's entrance, formed beneath the contact with paleosol V-S1 and loess horizon V-L2. There is also a significant number of loess blocks eroded from the cave ceiling that reach the height of approximately $1.53 \mathrm{~m}$. The cave window on the top of the roof (Fig. 8) suggests that the loess ceiling will collapse in the near future.

\section{Morphogenesis}

Loess caverns uncovered at the loess cliffs are relatively rare landforms. During intensive fieldwork research on the loess plateaus in the Vojvodina region since
1997, only three sites with similar morphology have been discovered: at the Titel old brickyard (SE part of the Titel loess plateau; Marković et al. 2005b), at the Potoranj site between Banoštor and Čerević villages and at site investigated in this study (Fig. 1). Thus, the processes and/or catalyst to read their formation is not widespread.

The morphogenesis of the investigated landform has been shown to be closely related to the sedimentological characteristics of the Late Pleistocene loess-paleosol sequences, however, this does not explain the initiation of the feature, nor its wholesale development. Fig. 9 summarises the proposed process of loess cavern evolution. In the initial phase, precipitation percolated through initial vertical loess cracks and partly accumulated as a hanging aquifer in sandy loess layer V-L1L2, above paleosol V-S1. These initial loess cracks were transformed into a closed depression (i.e. a sinkhole) which, due to presence of the black locust trees (Robinia pseudoakacia) around the initial depression, may have been controlled by vegetation influence. Gillijns et al. (2005) reported that there are large differences between the morphology of closed depressions in loess derived soils under forest vegetations and cropland. The mean diameter and mean surface of the loess depressions under forest are much smaller than observed in cropland area. However, the loess depressions in forests have a larger maximum depth and steeper slopes than those on arable land, contrary to wide and shallow depressions developed in the surrounding crops (Fig. 2). This trend is seen in the case of the Surduk loess sinkhole which has a smaller diameter but is deep, probably due to the locust tree presence above. Water percolation to an ephemeral hanging aquifer in sandy loess layer V-L1L2, above paleosol V-S1, leads to flow out at the cliff face and likely accelerated the initial loess sinkhole collapse. The short distance between the loess cliff and the collapsed sinkhole make the lateral removal of loess material possible (Fig. 9B). The proximity of the loess cliff also allowed the influence of climatic variations on landform evolution. These higher amplitude climatic variations probably involved frost action as morphogenetic factor, for example.

Because of the relatively high proportion of carbonate especially in the loess layers V-L1L1 and V-L1L1 (Antoine et al. 2009), processes of carbonate dissolution also contributed to formation of loess cavern. Thus, a processes of de-cementation allowed loose material to be transported by percolated water and out of the profile, allowing the erosion and formation of the cave. Quantification of the proportion of carbonate dissolution contribution to genesis of loess "cave" is a necessary part of further investigations. This fits in with the study of Zedeen et al. (2005) who explained the formation of the closed depressions on the neighboring Titel loess plateau as a 


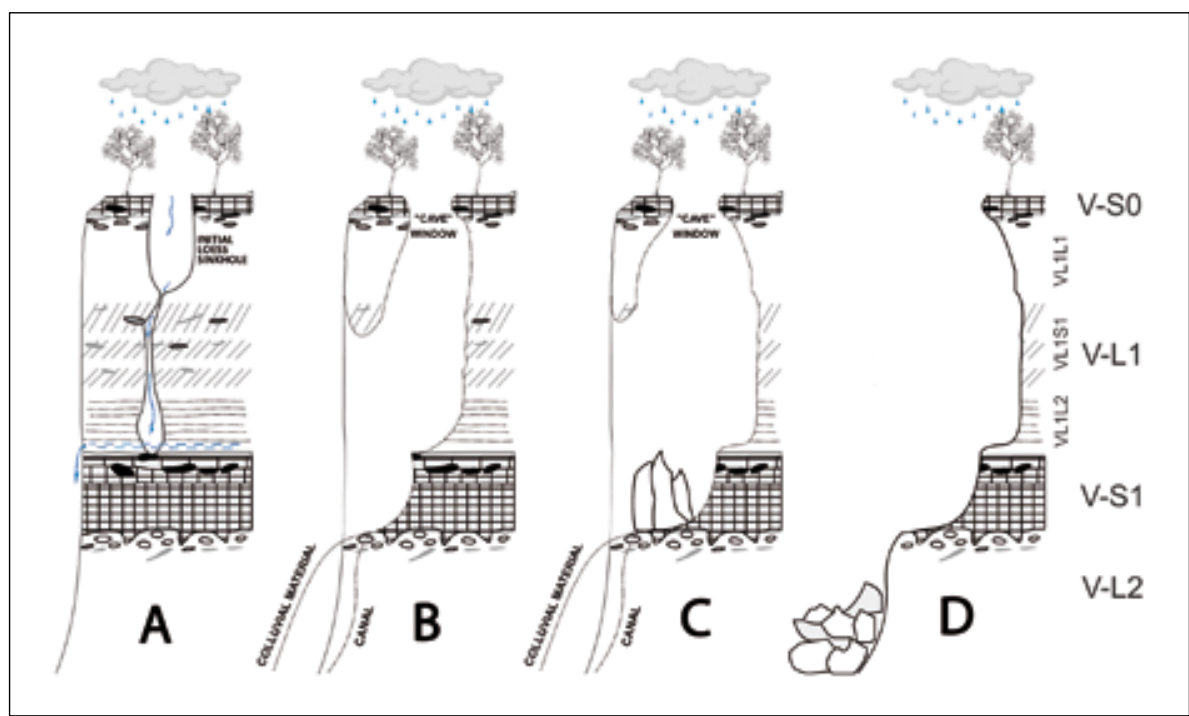

Fig. 9: Morphological phases of the loess cave evolution. Pedostratigra-

phy is the same as shown in Fig. 4.

combination of dissolution by seeping waters and initial aeolian relief predispositions.

During the next morphogenetic stage, water circulation through the initial pre-cave channel was likely initiated simultaneously with even more intensive lateral removal of loess material at the cliff. In the following morphogenetic stages the dimensions of the initial cave would have increased and broke through the adjacent cliff sides (Fig. 9B and 9C). The stability of the uppermost part of the loess cavern is maintained by very important root systems (van Beek et al. 2005) of several Robinia pseudoakacia trees (Fig. 8).

The formation of this type of loess landform is possible only near to cliffs because of limited possibilities for the lateral removal of loess material in laterally continuous sequences. This is confirmed by results of Zhu et al. (2002) who investigated tunnel erosion and sediment production in the hilly loess area in North China. They observed no significant correlation between runoff and sediment yield in most loess tunnels. Such an erratic relationship is ascribed to the rapid changes in runoff and sediment source area, the frequent occurrence of loess material collapses within tunnels, and the initiation of new tunnel inlets.
Because loess deposits are inherently unstable (e.g. Derbyshire 2001) the existence of the exposed loess "cave" is a temporally limited phenomenon. For example, the loess sinkhole at the Titel old brickyard discovered during fieldwork in 2004 (Marković et al. 2005b) is very similar to that at Surduk. Both are formed in the thick the last glacial loess layer VL1. During the subsequent fieldwork in 2005 collapse of the loess sinkhole was observed at the Titel old brickyard. Thus the final stage of morphological evolution will be related to collapse of the uppermost loess blocks (Fig. 9D). These changes in loess cliff morphology after loess cavern collapse could favour increasing of runoff velocity and thus rill and gully erosion (e.g. Valentin et al. 2005). Thus the formation of loess caves appears to be a potential part of the process of lateral erosion of loess sediments.

Zeremski (1955a, b) studied loess landforms and erosion of the steep Danube River bank between Zemun and Novi Banovci, including the current study location, as well as a detailed description of loess-paleosol sequence morphology on the eastern slopes of the Srem loess plateau. In these studies, no landform such as a loess "cave" was reported. As such, the loess cave should be older than 2004, the first time the cave was investigated, and younger than 1955. The age of Robinia pseudoakacia trees, which played an important role in the loess cavern formation, indicate a maximal period of this landform evolution between the last 10 and 15 years. During this relatively short interval approximately 75 tons of loess material was eroded, assuming an average density of $1.5 \mathrm{~g} \mathrm{~cm}^{-3}$.

\section{CONCLUSIONS}

The loess "cave" near Surduk is a young pseudokarstic landform formed by piping erosion supported with carbonate dissolution. A key role in the genesis of this landform was the short distance between the initial loess sinkhole that provided a possibility for the lateral removal of loess material. The presence of the Robinia pseu- 
doakacia trees around the initial depression modulated the subsequent evolution of the sinkhole. Also this type of vegetation appears to provide support for the loess cavern roof. Water percolation to an ephemeral hanging aquifer in sandy loess layer V-L1L2, above paleosol V-S1, and the subsequent flow out of the cliff accelerated the collapse of the sinkhole. During the next morphogenetic stages, the dimensions of the initial cave increased and broke through the adjacent cliff sides. The nature of the dynamic erosional processes on the steep cliffs of the soft loess sediment indicates a very limited lifetime of this pseudokarstic landform.

The loess cliffs on the Danube River bank near village of Surduk not only preserve a unique archive of Quaternary climate change, but also exhibit diverse and short-living landforms associated with the erosion of the deposits. These landforms preserve information on the processes of loess soil erosion that could help in future attempts to limit the loss of such material through conservation programs. In addition, the attractiveness of the site led to the locality being chosen by director Emir Kusturica as the main setting of his film "Black Cat, White Cat", awarded the Silver Lion for Best Direction at the Venice Film Festival. Thus there are aesthetic, cultural, conservation and palaeo-environmental research reasons for developing an effective and sustainable geoconservation procedure to protect this stretch of cliff and prolong the existence of the loess "cave", thereby introducing its significance to wider audience.

\section{ACKNOWLEDGEMENTS}

This research was supported by Project 146019 of the Serbian Ministry of Science and technological development and grant 114-451-00727-2009-02 of Provincial Secretariat for science and technological development,
ECAP Vojvodina. We are grateful to Jelena Ćalić and Ken O'Hara Dhand for their helpful discussion and constructive comments that significantly improved the quality of the manuscript.

\section{REFERENCES}

Antoine, P., Rousseau, D. D., Fuchs, M., Hatté, C., Gauthier, C., Marković, S. B., Jovanović, M., Gaudenyi, T., Moine, O. \& J. Rossignol, 2009: High-resolution record of the last climatic cycle in the southern Carpathian Basin (Surduk, Vojvodina, Serbia).- Quaternary International, 198, 19-36.

Bokhorst, M., Beets, C.J., Marković, S.B., Gerasimenko, N.P., Matviishina, Z.N. \& M. Frechen, 2009: Pedochemical climate proxies in Late Pleistocene Serbian-Ukranian loess sequences.- Quaternary International, 198, 113-123.

Bukurov, B., 1953: Geomorfološke crte južne Bačke.Zbornik radova Geografskog instituta Jovan Cvijić SANU, 4, 1-63.

Bukurov, B., 1975: Fizičkogeografski problemi Bačke.Odeljenje prirodno-matematičkih nauka SANU, pp. 209, Beograd.

Cholnoky, J., 1910: Az Alföld felszíne.- Földrajzi közlemények, XXXVIII, 10, 413-435.

Derbyshire, E., 2001: Geological hazards in loess terrain, with particular reference to the loess regions of China.- Earth Science Reviews, 54, 231-260.
Gillijns, K., Poesen, J. \& J. Deckers, 2005: On the characteristics and origin of closed depressions in loessderived soils in Europe-a case study from central Belgium.- Catena, 60, 43-58.

Fuller, M.L., 1922: Some unusual erosion features in the loess of China.- Geographical Review, 12, 570-584.

Fuchs, M., Rousseau, D.D., Antoine, P., Hatte, C., Gautier, C., Marković, S.B. \& L. Zöller, 2008: High resolution chronology of the upper Pleistocene loess/paleosol sequence at Surduk, Vojvodina, Serbia.- Boreas, 37, 66-73.

Halliday, W.R., 2007: Pseudokarst in the $21^{\text {st }}$ century.Journal of Cave and Karst Studies, 69, 103-113.

Heller, F. \& M.E. Evans, 1995: Loess magnetism.- Reviews of Geophysics, 33, 211-240.

Kertesz, A. \& F. Schweitzer, 1991: Geomorphological mapping of landslides in Hungary a case study of mapping Danubian bluffs.- Catenna, 18, 529-536.

Leger, M., 1990: Loess landforms.- Quaternary International, 7-8, 53-61.

Marković, S.B., Kostić, N. \& E. Oches, 2004: Paleosols in the Ruma loess section.- Revista Mexicana de Ciencias Geológicas, 21, 79-87. 
Marković, S.B., McCoy, W.D., Oches, E.A., Savić, S., Gaudenyi, T., Jovanović, M., Stevens, T., Walther, R., Ivanišević, P. \& Z. Galović, 2005a: Paleoclimate record in the Late Pleistocene loess-paleosol sequence at Petrovaradin Brickyard (Vojvodina, Serbia).-Geologica Carpathica, 56, 545-552.

Marković, S.B., Jovanović, M., Mijović, D., Bokhorst, M., Vandenberghe, J., Oches E., Hambach, U., Zöller, L., Gaudenyi, T., Kovačev, N., Boganović, Ž., Savić, S., Bojanić, D. \& N. Milojković, 2005b: Titel loess plateau - geopark.- In: Mijović, D. (ed), Institute for Nature Conservation of Serbia, Special Edition of the Institute for Nature Conservation of Serbia, 20, 2223 June 2004, Institute for Nature Conservation of Serbia, 177-184, Belgrade.

Marković, S.B., Oches, E.A., Sümegi, P., Jovanović, M. \& T. Gaudenyi, 2006: An introduction to the Upper and Middle Pleistocene loess-paleosol sequences in Ruma section (Vojvodina, Yugoslavia).- Quaternary International, 149, 80-86.

Marković, S.B., Oches, E.A., McCoy, W.D., Gaudenyi, T. \& M. Frechen, 2007: Malacological and sedimentological evidence for "warm" glacial climate from the Irig loess sequence (Vojvodina, Serbia).- Geophysics, Geochemistry and Geosystems, 8, Q09008, doi:10.1029/2006GC001565.

Marković, S.B., Bokhorst, M., Vandenberghe, J., Oches, E.A., Zöller, L., McCoy, W.D., Gaudenyi, T., Jovanović, M., Hambach, U. \& B. Machalett, 2008: Late Pleistocene loess-paleosol sequences in the Vojvodina region, North Serbia.- Journal of Quaternary Science, 23, 73-84.

Marković, S.B., Smalley, I., Hambach, U. \& P. Antoine, 2009a: Loess in the Danube region and surrounding loess provinces: The Marsigli memorial volume.- Quaternary International, 198, 5-6.

Marković, S.B., Hambach, U., Catto, N., Jovanović, M., Buggle, B., Machalett, B., Zöller, L., Glaser, B. \& M. Frechen, 2009b: The middle and late Pleistocene loess-paleosol sequences at Batajanica, Vojvodina, Serbia.- Quaternary International, 198, 255-266.

Marsigli, L.F., 1726: Danubius Pannonico Mysicus. Observationibis Geographicis, Astronomicis, Hydrographicis, Physicis; perlustratus.- Grosse, P., Alberts, Chr., de Hoodt, P., Herm. Uytwert and Franc Changuion; The Hague and Amsterdam.

Military Geographical Institute of Serbia, 1995: Topographic map of Vojvodina. 1:25.000.- Sections Zrenjanin 4-1 \& 4-3, Belgrade.

Móga, J. \& R. Németh, 2005: The morphological research of the basalt and loess covered plateaus in the Bakony mts. (Transdanubian middle mts. - Hungary).Acta carsologica, 34, 397-414.
Otvos, G. E., 1976: "Pseudokarst" and "pseudokarst terrains: Problems of terminology. GSA Bulletin 87VII, Geological Society of America, 1021-1027.

Rogers, C.D.F., Dijkstra, T.A. \& I.J.Smalley, 1994: Hydroconsolidation and subsidence of loess: Studies from China, Russia, North America and Europe.- Engineering Geology, 37, 83-113.

Rozycki, S.F., 1991: Loess and loess-like deposits.- Ossolineum. Publishing house of Polish Academy of Sciences, pp. 187, Wroclaw.

Self, C.A. \& M.J. Mullan, 2005: Rapid karst development in an English quartzitic sandstone.- Acta carsologica, 34, 2, 415-424.

Šebela, S. \& J. Čar, 2000: Velika Jeršanova dolina - a former collapse doline.- Acta carsologica, 29, 201-212.

Šušterič, F., 2000: Are collapse dolines formed only by collapse?- Acta carsologica, 29, 213-230.

Tang, G.A., Li, F.Y., Liu, X.J., Long, Y. \& X. Yang, 2008: Research on the slope spectrum of the Loess plateau.- Science in China Series E, Technological Sciences, 51, 175-185.

Valentin, C., Poesen, J. \& L. Yong, 2005: Gully erosion: Impacts, factors and controls.- Catena, 63, 132-153.

van Beek, L., Wint, J., Cammeraat, L. \& J. Edwards, 2005: Observation and stimulation of root reinforcement on abandoned Mediterranean slopes.- Plant \& Soil, 278, 1, 55-74.

Wray, R.A.L., 1997: Quartzite dissolution: karst or pseudokarst?- Cave and Karst Science, 24, 2, 81-86 (republished by permission in: Speleogenesis and Evolution of Karst Aquifers, 2; 2003)

Zeeden, C., Hark, M., Hambach, U., Marković, S. B. \& L. Zöller, 2007: Depressions on the Titel loess Plateau: Form- Pattern- Genesis.- Geographica Pannonica, 11, 4-8.

Zeremski, M., 1955a: Mikrooblici i erozija tla na lesnom odseku Dunava od Starih Banovaca do Zemuna.Zbornik radova PMF Geografskog instituta, 2, 4770 .

Zeremski, M., 1955b: Holoceni epirogeni pokreti na jugoistočnom delu odskea Sremske lesne zaravni.Zbornik Matice srpske za prirodne nauke, 9, 79-97.

Zhu, T.X., Luk, S.H. \& Q.G. Cai, 2002: Tunnel erosion and sediment production in the hilly loess region, North China.- Journal of Hydrology, 257, 78-90. 
